\title{
The Uniqueness of Athol Fugard's Characterization in his Drama
}

\author{
Margaret Njoki Mwihia
}

Mount Kenya University, School of Social Sciences

\section{Doi:10.5901/mjss.2015.v6n2s1p184}

\begin{abstract}
In the process of reading Athol Fugard's four selected plays it has been noticed that he has a unique way of presenting his characters to show his vision. The playwright presents us with characters in conditions that portray dehumanization of one race by another. He uses minimal characters that represent the larger population of South Africa.
\end{abstract}

Keywords: Literature, Language, Arts, Writers, play

\section{Background}

Critics and reviewers who have studied Fugard's plays have been examined to identify the gaps that the study can fill. According to Nyamdi( 2006) Africa's literature has organic link with the African society so that it reflects and settles a pathfinder's role on this literature. He adds that Africa goes where its literature takes it. This observation presupposes that the African writer has a great role in the education and re-education of his/her people. Indeed retrospection in African literature is not just reproduction of African history; it is writers' artistic techniques of moving away from the real to the ideal. Out of the raw materials of history the African writer constructs for us fictions; in so doing they create patterns of meaning out the jumble of fragmentations and chaos that the African reality presents. Through his/her creative imagination a writer aims at persuading his/her reader to view not only a kind of reality, but more important from a certain angle and perspective, a certain vision, though perhaps unconsciously. The writer's creative work both reflects reality and also aims at making the readers take a certain attitude to the reality presented.

Many illustrations from modern African literature indeed reveal the artistic chronicling down of the real sociopolitical, economic and many illustrations from historical realities on the continent. La Guma (cited in Wanajala 1973) observes that African literature concerns itself with the realities of Africa as it is true that all literatures of the world seem to have been created by particular social, political and economic factors prevailing at the time. Expressing African reality, in an appropriate style and form mirrors the writers' vision. African reality is that we are products of many cultures and historical circumstances. Most African writers from Achebe, Ousmane Sembene, Alex La Guma, Mazizi Kunene, Ngugi wa Thiong'o among others have successfully communicated African reality through their creative works, and by means of artistic judgment suggest the ideal; presenting their artistic judgment of the reality reflected in their creative works.

In South Africa writers, particularly black writers seem to have been influenced more by the ideals of the Apartheid system. This literature reflects the historical context of the country, the social and political scene in Apartheid South Africa. The Dutch, 'Boers' got to South Africa before the British in the $19^{\text {th }}$ century. They confiscated the people's land, later the British came and initiated the Anglo-Boer war between 1899-1902. The Blacks supported the British who won and then started the minority rule in South Africa. The question of colour became a great problem in South Africa and was used as an excuse to exploit the blacks. In 1910 the British passed an Act of Union that denied the Africans the right to vote. It upheld colour Bar and blacks couldn't struggle for economic and political emancipation.

\section{Characters in Athol Fugard's Plays}

As regards this study, Fugard makes use of two characters in each of the three plays and three characters in one of the plays. The plays are Hallo and Goodbye (1965), The Island (1972), Master Harold and the Boys (1982) and Blood Knot (1987). In Hallo and Goodbye two siblings Johnnie and his sister Hester are presented to stand for the disparity of the two races in South Africa. In The Island two inmates Winston and John are in a lonely cell. They are given roles to act in Sophocles' play Antigone that show the animosity of the white race to the black race. In Master Harold and the Boys, there are three characters. Two of them Sam and Willie are black servants working for the parents of Hally the white character. In Blood Knot two brothers Zachariah and Morris are presented to stand for the black and white race. 
Blood Knot first produced in Johannesburg, may be considered seminal in that it defines clearly the society of South Africa under apartheid, a society that Fugard loathed.Morris, who can pass for white, and his half brother, Zachariah, most definitely an African, share a one-room shack in the nonwhite slum of Korsten, near Port Elizabeth.

Zachariah is completely illiterate and a little slow-witted, but he has a menial job as a gatekeeper. Morris acts as homemaker-cleaning their room, cooking the meals, mending Zachariah's clothing, and preparing nightly footbaths for his brother.

In the year they have been together Morris has saved part of Zach's pay each week with the goal of accumulating enough cash to buy a small farm far from the area so that they can live as independent human beings.

Zachariah, however, is more interested in the present than the future. He remembers a friend who used to help him squander each week's pay on wine and women, and he is quite resentful of his brother's somewhat puritanical attitude.

To placate Zachariah, Morris suggests a pen pal, to be found in a newspaper listing women interested in this kind of activity. Not entirely convinced that this will take the place of "having a woman," Zach finally chooses Ethel Lange, and dictates a letter to Morris. She replies, enclosing a picture of herself that brings Morris to his senses. Zachariah has brought home a white friend.

The Island is an apartheid era drama, inspired by a true story, is set in an unnamed prison clearly based on South Africa's notorious, Robben Island where Nelson Mandela was held for twenty-seven years. It focuses on two cellmates, one whose successful appeal means that his release draws near and one who must remain in prison for many years to come. They spend their days at futile physical labour and nights rehearsing in their cell for a performance of Sophocles' Antigone in front of the other prisoners. One takes the part of Antigone, who defies the laws of the state to bury her brother, and the other takes the part of her uncle Creon, who sentences her to die for her crime of conscience. The play draws parallels between Antigone's situation and the situation of black political prisoners. Tensions arise as the performance approaches, especially when one of the prisoners learns that he has won an early release and the men's deep friendship is tested. The Island bears testament to the resiliency of the human heart.

Master Harold is a one-act that takes place inside the St. George's Park Tea Room on a wet and windy Port Elizabeth (South Africa) afternoon in 1950. No customers populate the restaurant and most of tables and chairs have been stacked to one side. Two black waiters, Willie and Sam, are on stage as the play begins. Willie is mopping the floor, and Sam is reading comic books at a table which has been set for a meal. Willie wants to improve his dancing skills but appears to have been deserted by his partner after he beat her. Sam offers Willie advice about improving both his dancing technique and his domestic relations. The son of the tearoom's owner, Hally, enters direct from school. He eats a bowl of soup and talks to the two men with whom he appears to have a close relationship

Hello and Goodbye tells the story of two dirt-poor white South Africans, a brother and sister, looking back on their childhood and trying to come to terms with their bleak, thwarted existence. At times their despair and hopelessness recall Beckett, though there is the faintest glimmer of hope at the end as a few apparently extinguished embers of love and sympathy begin faintly to glow.

The action takes place in a house that is little more than a shack in Fugard's native Port Elizabeth. Johnny, a man in his twenties, is living there alone, having recently buried his father, and is clearly on the edge of mental collapse, muttering constantly to himself, counting out the interminable seconds, minutes and hours, and fearing that he might have gone mad.

Then his older sister Hester arrives out of the blue. She was kicked out of the house by her grim, Calvinistic father many years earlier for going with boys, and has since become a prostitute in Johannesburg. Their father lost a leg in a railway accident years ago and Hester wants to get her hands on the compensation money which she believes has never been spent. Hester has no idea when she arrives that her father is dead, and Johnny doesn't tell her the truth, pretending that he is merely asleep in the room next door.

And though it quickly becomes blindingly obvious to the audience that the old man has snuffed it, Hester seems entirely deceived and evinces no interest in taking a look at the father who was largely responsible for shaping and deforming her life. Instead she sends Johnny into his room to bring out dozens of cardboard boxes, one of which she hopes will contain the missing cash. His vision is communicated through the different techniques that signify different values and the playwright's vision. The characters in the play are used symbolically to signify different values and enahance the playwright's communication of his artistic vision.

\section{Polyphonic Depiction of Characters}

In the play The Island it is through the heroine of the play 'Antigone' that the author opens the eyes of his audience to see the reality of the misuse of power as a theme in this play. 'Antigone' the character is a sister of two brothers who die in 
battle though on different sides aand she buries the body of one because it has been left unburied.This concurs with Weirtheim (2000) who states: "the audience however begins to realize that Fugard has chosen the Antigone story because it is a legend that embodies the history of protest and Winston's life is thus a history and legend in one."(93)The character Winston therefore stands for those who represent historical legends in South Africa. A good example is Nelson Mandela who in 1990 was released from a jail term he had served for twenty seven years comparable to Winston's cell.

It is only after the two inmates get a surprise call from outside their cell and then the news that John would be released in three months to come, that Winston sees his own image in old Harry another old prisoner who is jailed for life. Old Harry is a seventy year-old prisoner serving a life sentence like Winston and he worked at the quarry with such perfection that it was like he had forgotten himself.

Winston then says:

They have turned him into stone. Watch him work with that chisel and hammer twenty perfect blocks of stone every day. Nobody else can do it like him. He loves everything...

why he is here, where he comes from. That's happening to me John. I've forgotten who l'm. (71)

Winston realizes that he doesn't know himself and hence the quest for identity. 'Antigone' the character in the play Antigone is used to open the eyes not only of the character Winston but the audience too. This is the height of Fugard's vision for the people of South Africa. Winston sinks to the floor, helpless and tormented about the stretch life in the island and sees the reality of it. Fugard juxtaposes the life of Winston and the hopelessness with that of John who is about to be released to show the reality of the blacks in South Africa. Through Winston Fugard is showing that the blacks ought to see the reality about their position and fight for their rights. At last Winston who has been reluctant is now more than willing to stage the play Antigone and to take the part of 'Antigone'. He tells John: "Yes come, we'll be late for the concert to show that he is eager to act as he has now realized that the play is realistic and it carries some sentiments about his suffering. (73) Winston's voice is heard for the first time since they begun arguing about the cast in Antigone as carrying Fugard's social vision.

Fugard's hope is that as Winston has at least found himself in acting the part of Antigone, the blacks will find themselves in the character of Winston and get provoked to fight for their rights. John takes the part of Creon the King while Winston takes the part of 'Antigone' the sister of the two men who had both died in the same battle field though fighting on different sides. Antigone pleads guilty of burying her brother Polynices. When her charges were read as: "You are accused that, in defiance of the law, you buried the body of the traitor Polynices."(75) Her response was: "I buried the body of my brother Polynices here."(71) The author is showing us the strength of 'Antigone' in that she is impartial. She states categorically that when Polynices died in battle regardless of what side he was in, all that remained was a dead body which could neither harm nor help anybody. She says that what lay in the field belonged to God and tells Creon that though he is a king he is only a man. She goes on to state that as there are laws from man there are also laws from God and that is what she fulfilled. Antigone is brave. She doesn't fear even death and tells the king "Your threat is nothing to me, Creon. But if I had let my mother's son, a son of the land, lie there as food for the Carrion fly, Hodoshe, my soul would never have known peace."(76) She says the words with such finality that it is hard to believe that she is talking to a person who holds her life like King Creon. She has no fear because she stands for truth and says she feels no shame that she is sentenced for life imprisonment in the island. She is brave as she states that she goes to imprisonment without resentiment because she is not guilty.

In bringing in Antigone as a play within the main play The Island, Athol Fugard's vision is that the blacks should realize their position and they should like Antigone be brave enough to take their position. Antigone's voice is Fugard's vision in that a person who is sentenced unfairly by unfair laws remains innocent although he may suffer.Like Polynices, they are viewed as traitors and they deserve no honour. Brave people like Antigone should arise and stand for the truth even though it means going to prison.

Winston and John act in prison and end up sending a message even to the rulers. Antigone tells the bitter truth to Creon the king: "I buried my brother. That is an honorable thing to do. All these people in your state would say so too, if fear of you and another law did not force them to silence."(76) At the end of the play The Island the audience watches the two inmates Winston and John remove their costumes and their hands and legs are once more tied in handcuffs and ankle- chains respectively and they run their usual three legged run back to their cell. This is a clear suggestion that the two races in South Africa are tied in a way that they can't part. In order for them to find their identity, they must work together to get free from their handcuffs and shackles. Fugard's vision for them in this play is that they can find 
themselves through the character of Winston acting as Antigone to symbolize the oppressed blacks and John acting King Creon to symbolize the apartheid rule that oppresses the less fortunate.

Antigone in her speech tells the truth about the oppressive rule fearlessly. When asked: "what did you plead to the charges laid against you? Guilty or not guilty?"(75) She bravely answers: "Guilty."(75). She then asks Creon whether he is God to which he answers by telling her to watch her words. She is fearless and tells him to hurry up and sentence her because he is already decided, "Your sentence on my life hangs waiting on your lips."(75) She is sure that Creon who stands for the state is already decided on her sentence. The fate of the black man is already decided by the white man in that he is inferior and therefore he has no say over anything including his own life.

In the play Blood Knot, Fugard uses two characters to illustrate the quest for identity. Zachariah who represents the black is presented as one who is deprived of his rights as a result of his black skin. At one time when he tells his brother Morris that he needs a woman, he is told to get himself a pen pal. This issue comes about when Zachariah looking through the window sees two donkeys mating and it dawns to him that it was a whole year since he had a woman. He remembers the good times he had with an old girlfriend known as Minnie. In the company of his friends they would go out at night and have women. "Hey! I remember now! By hell! About Minnie. How did I forget... it was a woman! That is what we had when we went out at night woman!"(11) Furgard's social vision here is that the African should one day be able to enjoy human rights like the whites.

Morris who represents the whites in this play, ignores his brother and tries to put off Zachariah's thoughts from what Zachariah is deprived of. He tells him, "Supper is ready."(11) Zachariah is adamant and tells him "You are not going to make me forget. I won't, I'm not going to. We had woman, I tell you. Woman, Woman!Woman!" (12) The use of the short sentences, exclamation marks and the full stop show immediacy.

The problem of the South African blacks needs attention now and not tomorrow. Fugard's vision is that the issues affecting the blacks are not unimportant as the whites think. He makes Zachariah stubborn on the issue of the immediate need for a woman. "What do you think I am? Guess! Two legs and trousers. I am a man. And in this world there is also woman, and one has to get the other. Even donkeys know that."(12) The black man in South Africa is a man who has human rights equal to the white man. Zachariah remembers with nostalgia his days with Minnie and the way they would go out and would booze and enjoy but when his brother Morris arrived and everything changed.The following words are meant to show that Morris came to interfere with his brother's life. His arrival brought no good.

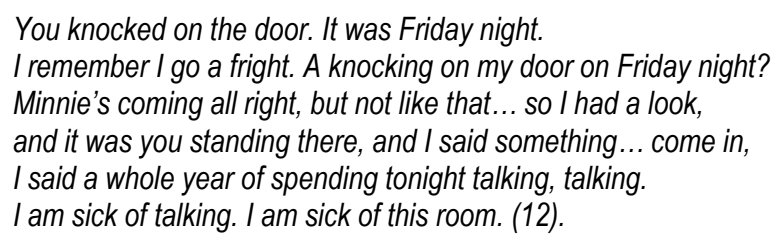

This talk has finality. The Blackman is tired of remaining enclosed. Zachariah says he has lived his life for ten years and had fun with the friends of his choice before Morris arrived. Fugard makes use of a flashback to show that the black man was doing okay before the white man arrived. He had all that he needed. Socially the black man was doing well and he did not need to work for the white man for the essentials. Zachariah states that he was alone for ten years and he had no worries about his feet, a future or having supper on time. This shows that before the white man arrived in South Africa, the blacks did not need to work and eat at a set time but rather did their things at their own time in a relaxed manner.

Zachariah has swollen feet and has to use foot salts because his job at the gate demands that he stands at the same spot a whole day. Supper has to be eaten at a certain time so that he can sleep and get up early in order to go to work. There is a clock with an alarm to remind them that it is time for a certain activity. The clock is manned by Morris. This means that the white man is the one who decided what the black should do and when, Morris tries to get Zachariah away from his thoughts about having a woman but he refuses. He asserts himself as a human being. He wants his identity as a man. Morris tells his brother that he would think about it but Zachariah insists that if he was doing so, it should be immediately. Morris says: "I'm still busy, Zach it takes time. Shall I talk some more?"(14) Zachariah is still very adamant and tells him that if there was anything to be talked of it was about a woman. In a flashback with nostalgia, Zachariah tells his brother about one of the girls he had experienced. "The first one. My very first one... her name was Connie...Connie Ferreira... it was the year when you [was] away."(16)

In this conversation Athol Fugard is stating that before the whites arrived in South Africa, the blacks had their own life which was enjoyable. The arrival of the white man reduced the black man to one who could not do anything for himself. Zachariah needs a woman but it is the brother who should decide who and when. Morris is talking about saving Zachariah's hard earned money but Morris is the manager. Fugard's vision here is that the blacks should be let loose so 
that they can work and manage their hard earned economy. After the long argument, Morris gives up and entertains the talk about woman but still does not let his brother loose. He leads him to buy a newspaper to look for a pen-pal. Zachariah has to buy the newspaper with his pay the next day and both of them would look at the pen-pal column for names. Zachariah doesn't know how to read so his brother Morris would read for him and make the choice. The question here is, whose pen pal is she going to be? Another question also is what is a pen-pal to a man who has not had a woman for a whole year? It is like Fugard is asking these questions through the dialogue of the two brothers.

The black man in South Africa is deprived in all ways. Fugard uses the sex image not because he is vulgar but because he wants to show the level of deprivation for the black man. He juxtaposes the black man's deprivation of sex which is a need to the freedom the donkeys have as they can mate anytime anywhere as Zachariah had watched them do through the window. Morris reads the bible to his brother and then mends his torn coat telling him that he is helping him. "I am helping you, aren't I Zach? I want to believe that. You see... there [was] all those years, when I was away." The white man tries to justify his presence in South Africa and misuses religion to show that he is helping the black brother to move on. When Zachariah asks Morris why he came and why he stayed, Morris answers that: "we are brothers, remember"(19). Through a dialogue Fugard shows how the white man imposed his presence to the black man. The playwright gives the two brothers invisible parents. Morris asks a rhetorical question that shows emphasis on their confusion on the issue of being brothers.

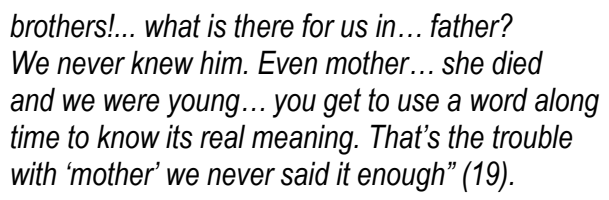

The two brothers have a great problem. They don't have the bond people need to be brothers. They have an acute quest for identity. The whites in South Africa have a claim for South Africa as their mother land. The blacks too have a greater historical claim. However they don't know how they started living together and who has more right over South Africa than the other. In an internal monologue, Morris goes into a flashback and remembers how one year ago he came to live with his brother. He walked a long distance and he remembers he was lonely and his brother Zachariah was the only person who could comfort him. Morris says that when he arrived, he felt a stranger because no one recognized him after all those years. However, for a little while he enjoyed the respect accorded to him due to his colour. "I could see they weren't sure and waiting to carry my bundle" (20).

Here we encounter the voice of Morris stating that the whites feel superior to the blacks. The whites enjoy respect from the blacks not because they deserve it but because of the racism in South Africa that makes blacks feel inferior. They look at the whites like they are gods to be worshipped. However, by making Morris feel a stranger, Fugard is showing that the whites are not comfortable after all. In the same monologue Morris tells of how he wore his brother's coat as he was asleep. He had looked at the coat while they were talking but when they slept; he woke up and put it on. "And that night, in the dark, when you slept, I put it on... because, I've got to get to know him again, I said, this brother of mine, all over again."(21) We are left asking why Morris had to take the coat in darkness while his brother was asleep. Fugard has the answer through Morris in the internal monologue below. This is the voice of Morris saying what Fugard needs to say to open up the black man to see the reality of where apartheid places him.

The white man in South Africa got into the life of the black man while the black man was unaware, unconscious and naïve. Morris says it all. The effect on the white man as he says is that he was going to exploit the black man. Morris says he feels pain all the same. This shows that even as he exploits his brother, he feels guilty because Zachariah is still his blood brother. "Pain, and all those dumb dreams throbbing under the raw skin, I feel, you see... I saw you again after all those years... and it hurt."(21) The white man suffers alienation as he exploits the black man.Fugard uses the voice of Morris to express ithat the whites feel it is wrong to exploit the black man but they still do it because there is a force that compels them to do so. This force is the colour discrimination that prompted the separate development popularly known as apartheid. Apartheid and all the evils that go with it give no pleasure even to the white man. All it brings is guilt and alienation. In "South African writing- a Brief survey" an article in Waruinge $(1978,195)$ he argues that the characters in Gordimer's novel, as in real life, live together but remain strangers, each following his or her own line of development. This sort of alienation is evident in Fugard's Blood Knot where now the two brothers Morris and Zachariah are living in the same room and yet each one has a different line of thought. Zachariah wants things done immediately. His brother Morris thinks that Zachariah can wait.Morris keeps on postponing. He can't understand why Zachariah is in a hurry because he is not in his shoes. The needs of the blacks should be attended to with immediacy but the whites seem not to understand. 
When the two brothers finally get the names of the pen- pals, Morris tells Zachariah to choos. He tells him: "I can't get hot about a name on a piece of paper; it is not real to me."(23) This is true Zachariah needs a woman not a name. It is all so mechanical. The blacks need to be given social, political and economic rights immediately not any promises. Morris asks his brothers whether if the pen pal was ' Connie' an earlier girlfriend of Zachariah, it would be real enough to which he replies yes because to him 'Connie' is a reality as he already has experience with her. Zachariah hasn't found himself. He is trying to find himself but he is yet to do so in South Africa. The black needs his identity in his home country and that is the social vision Fugard has. It is even worse when Morris has to write a letter to Ethel because Zachariah doesn't know how to read or write. Morris writes and Zachariah wonders whether the pen- pal is his or his brother's.

When Ethel replies and sends her photograph, Morris is shocked to realize that Ethel is a white. Zachariah is exited that a white woman has written back to him. Morris knows there is trouble because of the apartheid law. In the photograph, Ethel brother's foot is sticking at a corner and she explains in the letter that he's got a motorbike and she has been with him riding on the back. Morris insists they burn the letter and the photo or else if it was discovered by the authorities it was going to be a lot of trouble. In the apartheid regime, blacks were not allowed to associate with whites. Fugard's character Zachariah is naïve and he can't understand why and insists on replying the letter. He knows that motorbikes and boots are associated with policemen but he insists. Morris tries all he can to discourage him. Fugard wants to show his audience the magnitude of the evils of apartheid in allowing Zachariah to enjoy a day dream of a time with Ethel and talk about a car that he would fuel. Fugard is telling his vision for the future of South Africa.

The conversation drifts from Ethel to their mother when Morris tells his brother that he's playing with fire in trying to reply Ethel's letter and to retain hers and also keep the photograph. Zachariah tells Morris that he never had much to play with reminding him that he really wanted to but their mother only gave him her old cotton reels to play with. The mother favoured Morris and gave him toys because he was younger The white man has always had his way in south Africa as opposed to the black man.

That song was sung by the mother for her son Morris. Morris is amazed but Zachariah also tells him the mother did not sing it for him. It was her song. The song she sang for Morris was a lullaby '... you'll get to the top.'(48) The mother's voice elevates the light skinned son.This tells us that the mother put the light skinned child ahead though he was younger.

The two brothers enact their childhood and pretend to be driving and Zachariah is the one who is driving as. Morris looks through the window and he is supposed to tell his brother what he sees. Zachariah drives on until as they cross a river and go up hill to the top and then they go down again, Morris stops him and he slams on the brakes asking why. They see butterflies all around them. It is then that Morris smiles and says: "we have found it, Zach. We have found it! This is our youth" (50). The two brothers have been looking for their identity. They have now found it. Their voices assert that they have found their identity.Morris has realized his position. He is light skinned and so he is superior to his brother.

The two brothers however belong to the same mother. She is black but has got a white boy from a white man. She loves the two boys. They are brothers. They continue acting their childhood and they enjoy it. The butterflies are white. This is symbolic of the white race. Zachariah is black but they had a good time until their mother died. The two boys were left on their own. Morris left taking the long road away from his brother. When he came back, it was because he felt alone and unfulfilled. The brothers lived together, one working and the other managing. This tells us that the white man cannot do without the black man in South Africa. Each one of them needs the other. They complement each other. There was peace until the arrival of Ethel the white pen- pal into their lives.

When the two brothers see Ethel's photo, the boots, the motorcycle and the notion that they are symbolic of the white man, life changes. Ethel is a young girl full of life but she cannot share it with a black as the apartheid law doesn't allow. The people of South Africa whether black and white need to find themselves in regard to their social life. Economic status also is a big issue. The blacks are poor. Ethel asks Zachariah in the letter whether he has a car. This is a dream according to the status of Zachariah who is a black, poverty stricken and illiterate man but he cheats her in his reply.

Another letter from Ethel, further complicates issues between Zachariah and his brother. The last letter and photograph were almost burnt by his brother. He is quiet about the second one but his dilemma is that he can't read. The black man in South Africa has to depend on the white man for all his matters. Morris reads the letter and tells Zachariah that Ethel would be on holiday at her uncle's home which was not very far from the two brothers' home and so asks Zachariah to meet him and her friend so that they may have a ride in his car. At this juncture, the two brothers don't know what to do.

Morris then brings the issue of moths he had seen earlier in order to make his brother to drop the complicated issue about Ethel. The moths symbolize the blacks. When moths see a light, they play around it and most of them die. The blacks playing with whites will end up in trouble. Morris tells his brother to give up and tell Ethel the truth that: "I was born a dark sort of boy who wanted to play with whiteness"58. 
The whites in South Africa won't allow the blacks to play around with their girls. The apartheid law does not allow it. Morris tells his brother to think quickly and decide how to escape from the problem. Ethel's uncle and brother are policemen and they were bound to get Zachariah and punish him. "They have ways and means, my friend. I mean ways like confinement in a cell, on bread and water for days without end."(59) The black man is heavily punished even for emotion like loving a white. Fugard brings in the idea of dreams. He gets into the subconscious. The blacks can be jailed for dreaming about whiteness. Morris tells his brother:

\section{All they need for evidence is a man's dreams. Not so much his hate. They say they can live with that. It is his dreams that they drag off to judgment. (59)}

In using such intimidation Fugard is stating that the white man wants to kill the dream of the blacks that they can ever have equality. The white mandoesn't care about the hatred the blacks may have for being oppressed. What the white man wants is to hinder the dream that one day the blacks and whites may enjoy social equality. The conversation then leads to Zachariah realizing that he is black and Ethel is white and so their meeting is not possible. He ends up giving her up to Morris who can pass for white. Zachariah has now found himself and his position in South Africa.

Athol Fugard's vision can only be possible when the blacks realize their position, hate it and then fight against it. Zachariah tells his brother in answer to "the whole, rotten, stinking lot is all because I am black. Yes. That explains it, clearly. [Which is something.] I mean when a man can see 'why Quite clearly, it's something. Think of those who can't."(62) This is what Fugard does. He opens the eyes of the audience through this realization. It is then that Zachariah states:

I take it. I take them all. Black days, black ways, black things.

They're me. I am happy... I am on my side; they're on [theirs]...

I will be what I am.

They can be what they like. I don't care. (63)

The black man is South Africa being blinded by the white man was the problem that Fugard wants to tackle. He wanted to show that a black can do things better if he believes in himself and what he is. The blacks should get over the intimidation of the whites. White in this sense goes with power. Zachariah tells his brother to meet Ethel not for him again like in the way he wrote the letters but now he gives up the idea of a pen pal. He gives up his savings so that Morris can buy new clothes in order to meet Ethel but not for him anymore. Zachariah has nothing to do with Ethel now. He is aware that their relationship is of no use to him. He can never get satisfaction by having an imaginary relationship with a pen pal he can never meet. The black man is now aware that apartheid can do him no good and therefore has nothing to do with it.

In this episode, Fugard uses Ethel to bring consciousness to the two brothers, that one is white and the other one is black although they are brothers. The white brother enjoys the benefits that should be his brother's like the new suit and the pen pal because of his colour. Fugard wants the blacks to see the truth that they are missing their own benefits because they are discriminated for being black. Zachariah goes to buy the clothes and brings them to his brother. Morris had told him: "Go to a good shop. Ask for the outfit, for a gentleman."At the shop, they almost called the police. This is because a black is not regarded as a 'gentleman' because of his colour. However, when they saw his savings they sobered up and welcomed him. This shows that to the whites, the blacks are only useful to them as long as they are being exploited.

South Africa is the mother land for two brothers Morris and Zachariah. The blacks and the whites are brothers as represented by the two brothers so they need to know why one should be elevated over the other. Before they can enjoy the brother hood, certain things must rectify. They must find themselves first. One is black and he is the elder one. The younger one is white. The reality is that they are blood brothers from the same mother who is symbolic of South Africa.

Zachariah has found himself and he is happy about it. Morris admires the moths who symbolize blacks and their warmth. He knows he is white like the butterflies. He has also found himself and that is what Fugard wants for the two brothers who represent the two major races in South African. The voice of Morris is used here to express his admiration for the warmth in the moths whose colour is different from the butterflies. Fugard's vision is that the white man should see the blacks as human beings with warm feelings.

Johnnie and his sister Hester in Hello and Goodbye are trying to find themselves. Fugard gives the two an invisible mother and father. We only know about them through their children's dialogue. When Hester arrives in their home she 
says 'Hello' to her brother Johnnie who is reading a comic book. Hester is not even sure whether there is anyone at home. The home is empty and lonely. She had left some years back because she could never agree with her father. Hester demands a welcome but Johnnie seems not to know her and even if he does, he does not look interested. Fugard is using the two to show that they are strangers to each other although they are siblings. Hester is forcing herself to Johnnie. They are not sure of their relationship.

Hester tries to prove her identity to Johnnie to show that she is part of the family.

\author{
That was our room... but after Mommie died \\ I went you moved here... I was working at \\ Astoria café when you got big and Daddy \\ got worse it was you who used to look after him.(8)
}

Hester didn't love this place and still doesn't but she has come back. When asked why she said that she was only passing. The whites don't love South Africa as a home but rather for what it has. Hester states: "It is hello and good bye".(11) The audience are meant to understand what ' hello' and 'goodbye' means. Fugard uses the voice of Hester to express that the whites came to visit. The statement 'Hello' is normally said by a person who finds another somewhere and says it as a way of greetings and announcing arrival. Hester has found her brother in the house and therefore she says hallo as a greeting. She had left the home but she has now arrived. She has come but she is leaving. The white man came to South Africa in the seventeenth century but doesn't love South Africa. They like Hester are on a mission. The mission is materialistic based and once accomplished, Hester will leave. She doesn't care about her father's sickness. She has come for her inheritance. Johnnie can continue taking care of their father but it is money she is interested in.

Fugard in using Hester to look like an ungrateful child who wants her father dead so that she can get her inheritance is two edged. On one hand Hester is sending a message that the whites as well as blacks are tired of the old system of apartheid. Apartheid should by now be a thing of the past. The system is old and unworthy. The father is sickly, groaning and very boring. According to Hester, her father's sickness is overdue and he should be dead to set everyone free. If he were dead as should be, Hester could get her share of inheritance and John would be free to do his own business independent from his father and free from nursing a person who will probably never recover.

Some whites like the playwright himself really wished for apartheid to die. Even when Johnnie replied with some optimism to show that the old man was improving, Hester would brush the hopes away and change the topic about death to asking whether the father remembered or missed her. Johnnie would then tell her outright that the old man hated her and had said he would never talk about her. Hester would then as a matter of fact remind her brother that even if the old man hated her, she was still his daughter and when he died, she would get half of his property according to the law because she was a daughter of his. When the brother insists on the reason why Hester has come home after all those years she categorically states that she is only passing through and that her name is Hester smite. This is to tell Johnnie that she seriously is a member of the family and that she has come not to stay but to get what rightfully belongs to her and then leave him alone.

On the other hand Hester is also sending a message that she wants her own life separate from her brother. The reason she left home was that she was bored and none understood her. She says "None of you know me..."I will say it again "None of you know me". The repetition of" none of you know me" is meant to emphasize that Hester although a member of the family is very different from what anyone would imagine. This is a member of the family who is selfish and greedy. Hester cares only about herself. She is not interested in how others feel or get affected by her behavior. In the situation of south Africa of that time, such a character could represent the whites who are selfish and don't care about what the blacks go through. They didn't care about the political, social, economical problems the blacks went through. Their interest was only on what they got in terms of material wealth from South Africa. Hester insists that when the father dies, half of what he owns goes to her.She is however not interested in his health. The white man is not interested in the well being of South Africa as a nation but rather on the material products.

Fairy tales are about an imaginary life where things happen so well and end up well. Fairly tales according to Hester ended many years ago. As she says, that she has been a whore who gets money from everybody not caring about who he is. She cares not for brothers or father's . Her concern is that she is a woman and the other one is a man. She has no human feelings. There is biblical allusion in that there is a sin committed by her in those deeds but she doesn't care. The only thing she cares about is money and that is why she will have the courage to get into her father's room to ask for her share when she wakes up. There is no evil that Hester cannot commit. This tells that the whites can do anything if only it is to benefit them even if it means to oppress the blacks. 
Johnnie is so concerned about morals and tells her not to do such thing to her father but she doesn't care. Fugard is telling the audience through Hester that the whites don't care about how immoral it is to treat the blacks the way they do.The regime cares about what they gain from South Africa and not the way through which they get the material. It is then that Johnnie asks his sister to get her share to which she promises she would. They then agree that Johnnie would go to his father's bedroom and bring all the boxes to Hester so that she can search them. It is a tedious job but Johnnie does it because he doesn't want Hester to go inside and then discover that the father is not in the room.

\section{Conclusion}

As discussed in this paper, it is clear that Fugard has a unique way of making use of few characters so elaborately that the reader is left satisfied that the playwright needs no more to express his vision.

\section{References}

Adedoja, E.(2010). Social relevance of African literature to the promotion of social values. Kwara State Polytechnic Ilorin October 2010, Volume 7, No.10 (Serial No.82), 2010.

Alan, F.(1970). The Turn of the Novel: The Transition to Modern Fiction. London: O.U.P.

Alan, P.(1948). Cry the Beloved Country. New York: Scribner.

Albert B. L.(1975). The Singer of Tales. N.Y.: Atheneum.

Albert, W.(2000) .The Dramatic Art of Athol Fugard. UK: Indiana University Press.

Alex, I. (1964). What Is Sociology? London: Prentice Hall.

Barthes, R. (1967). Elements of Semiology (trans. Annette Lavers \& Colin Smith). London: Jonathan Cape.

Baudrillard, J. \& Poster, M. (1988). Selected Writings. Cambridge: Polity Press.

Best, S. (2003). A Beginner's Guide to Social Theory. London: Sage Publications.

Blessler,C. (2007). Literary Criticism: An introduction to Theory Practice. $4^{\text {th }}$ Ed. Upper Saddle River: Pearson Education, Inc.

Bolagun, P. O. (2003). Archetypes in African Literary Oral Literary Traditions: an Exampl J. P. Clark's

Brinkerhoff, D., Lynn, K. and Suzanne T. Ortega. (2005) Essentials of Sociology. USA. Wadsworth Publishing Company.

Brutus,S. (1969). The Writers in Modern Africa. 3 ${ }^{\text {rd }}$ Ed. New York:Africana Publishing Corp. Caesar, J. (1973). Drama. U.S.A: Scholastic Magazines Inc.

Carrigan, R. (1970). Theatre in the 20th Century. New York: Tulane.

Cass, J. (1967). Literature and Young Children. London: Oxford University Press.

Cassady, and Pat.(1975). Theater and Drama. USA: NTC Publishing Group.

Chatman, S. (1981). Literary Style. London: Oxford University Press.

Dennis, D. and Cosmos Pieterse (1972). African WritersTalking. London: Heinemann Educational Books Ltd.

Dennis, E. and Cosmos Pieterse.(1972). African Writers Talking. London: Heinneman Educational Books Ltd.

Dennis, W. (2003). Athol Fugard: Writers and Their Work. Britain:North Cote.

Durosimi, E. and Marjorie Jones. (1996). New Trends and Generations inAfrican Literature. North Cote. London: James Currey.

Eco, U. (1976). A Theory of Semiotics. Bloomington, IN: Indiana University Press.

Edgar, R. (1999). Writing about Literature: Brief 9th Ed. New Jersey: Prentice Hall.

February, V. (1981). Mind Your Colour. London: Kegan Paul InternationalLtd.

Fonagy, P.and Bateman. (2008). Psychoanalytic Constructs. New York: Guilford Press.

Fonagy,P. and Bateman. (2006). Mechanism of Change in Mentalization based Treatment. United Kingdom: JohnWiley.

Fonagy,P. and Target.(2003). Psychoanalytic Theories. New York: Whurr Publications

Friedman,A.(1970). The Transition of Modern Fiction. London: Oxford University Press.

Fugard, A. (1987). Blood Knot. New York: Oxford Universitity press.

Fugard, A. (1976). The Island. New York: Vikings Press.

Fugard, A. (1984). Master Harold and the Boys. New York: Penguins.

Fugard, A. (1974). Hello and Goodbye. New York: Oxford University Press.

Gachukia E. (1978). Teaching of African Literature in Schools. Nairobi: East African Educational Publishers.

Gergen,K and Mary Gergen. Social Psychology. New York: Hacourt Brace Jovanovich.

Goldthorpe, J. (1982). An Introduction to Sociology. London: Cambridge University Press

Gray, S. (1982). Athol Fugard. Johannesburg: Mc Graw-Hill.

Guerin, W. etal. (1999). A Handbook of Critical Approaches to Literature. New York: Oxford University Press.

Hacker, D. (1969). Rules for Writers 3rd Ed. NewYork: Bedford Books of St. Martins Press.

Hatch, J. and Ted Shine. (1996). Black Theatre. U.SA: Macmillan Publishers.

Head, D. (1994). Nadine Gordimer. Great Britain: CambridgeUniversity Press.

Hill, E. (1981). The Theatre of Black Americans. Vol. 11. Jersey: Prentice Hall.

Hofer, M. (1981). The Roots Of Human Behaviour. USA:W.H.Freeman\&Company.

Mott ,E. P. (1965). The Organisation of Society. USA: Prentice Hall Inc. 
Mphalele, E. (1972). Voices in The Whirlwind and Other Essays. New York: Hill and Young.

Ngara, E. (1982). Art and Ideology in the African Novel. Nairobi: Heinemann.

Nkosi, L. (1983) Tasks and Masks. Nairobi: Heinmann

Norton,P.and Joseph Esposito.(1994).TheNewEncyclopediaBritannica.vol28. Chicago :Encyclopedia, Britannica Inc.

Nuebeck, K.,Mary Nuebeck and Davita Glasberg.(1979) Social Problems. New York: Mc Graw Hill Co.

Parker, K. (1978). The South African Novel in English. New York: Macmillan.

Paton, A. (1948). Cry the Beloved Country. New York: Scribner.

Peck, J. and Martin Coyle. (1993). Literary terms and Criticism New Ed. London: Macmillan.

Peirce, C. S. (1931-58). Collected Writings (8 Vols.). (Ed. Charles Hartshorne, Paul Weiss \& Arthur W Burks). Cambridge, MA: Harvard University Press.

Peters, J.M. (1987). In het teken van het beeld. Beknopte introductie tot de semiologie. In J. Bardoel \& J. Bierhoff (Eds.), Informatie in Nederland, theorie, achtergronden. Groningen: Wolters-Noordhoff

Ramage, J., John Ben and June Johnson. (1996). The Allyn and Bacon Guide to Writing. New York: Bedford books of St. Martin's Press.

Robert, C. (1970). Theatre in the Twentieth Century. New York. Tulane Drama Review.

Robert, H. Lauler.(2005). Social Problems and the Quality of Life. USA: Mc Graw Hill Co.

Robert, R.K. (2005). Psychology. USA: John Willey \& Son Inc.

Rose ,I.. P., Peninah M. Glazer and Myron Peretz Grazer. (1990). Sociology. USA. Prentice Hall.Inc.

Saussure, F. de (1983). Course in General Linguistics (trans. Roy Harper)

Scarlyn, N. (1937). European Drama. Great Britain: C. Tringlin \& Co.

Tyson L. (2005). Critical Theory Today. New York: Rout ledge.

Wa Thiong'o, N. (1991). Moving the Centre. Nairobi: Heinemann Educational Books.

Wanjala, C. (1973). Standpoint on African Literature. Nairobi East African Literature Bureau.

Wellek,R.andAustinWarren.(2000). TheoryofLiterature.Britain:JonathanCape.

Wertheim, A. (2000). The Dramatic Artof Athol Fugard. UK: Indiana University Press.

William, R. (1968). Drama in Performance. Great Britain: Alden and Mow.

Wilson, N.S. (1937). European Drama. Great Britain: C. Trinling\&Co. 